ment of any avail, and even that of questionable utility, was thorough eleaning out of the alimentary canal, accompanied with mild febrifuges and good hygiene. Diphtheria antitoxin has not been tried yet, and the epidemic is of too recent date for any particular benefit to be derived from the application of electricity.

In accordance with a custom of this vicinity, no postmortems in this class of cases are performed.

\section{VOCAL FREMTTUS IN LARGE PLEURAL EFFUSIONS.} 1

\section{W. J. CALVERT, M.D. Columbia, Mo.}

Vocal fremitus is usually diminished or absent in pleurisy with effusion. In the literature at hand, fremitus in large effusions is rarely mentioned.

History of Case.-In a young adult, white, male, with suspected left-sided pleurisy, examination revealed increased vocal fremitus and bronchial breathing throughout the left side. After withdrawing 1,500 c.e. of fluid, an absence of vocal fremitus throughout the left side was noted. After several tappings practically all the fluid was removed. During this time vocal fremitus gradually returned, but was less than normal when the patient was discharged.

Arneth, ${ }^{2}$ in his paper on Vocal Fremitus in Croupous Lung Inflammations, says that the increased tension of the thoracic wall can not prevent the fremitus, because in pleurisy with large effusions and much pressure the fremitus is often increased.

Lax elastic membranes absorb vibrations, but when sufficiently tense transmit them. In this case the mediastinal membranes were tense and transmitted the vibrations of the trachea and large bronchi to the thoracic wall. When the tension was removed from these membranes by withdrawing 1,500 c.c. of fluid the vibrations were absorbed before reaching the thoracic wall, when vocal fremitus was lost, as is usual in pleural effusions.

It may be said that in pleurisy with effusion vocal fremitus is diminished or absent; it reappears, intensified, when the pressure of the fluid is sufficiently high; disappears when the tension is reduced, and gradually reappears as the fluid is removed or absorbed.

\section{New and Non-Official Remedies}

THe following aRTicles have BeEN tentatively aCcepted by the Council on Pharmacy and Chemistry of the American Medical association for inclusion in the proposed annual, "New and Non-official Reanedies." Their accept. ANCE HAS BEEN BASED LARGELY ON EVIDENCE SUPPLIED BY THE MANUFACTLRER OR HIS AGENT, BUT TO SOME EXTENT ON INVESTIGATION MADE BY OR UNDER THE DIRECTION OF THE COUNCIL. CRITICISMS AND CORRECTIONS ARE ASKED FOR TO AID IN THE REVISION OF THE MATTER BEFORE FINAL $\triangle$ CCEPTANCE AND PUBLICATION IN BOOK FORM.

THE COUNCiL DESIRES PHYSICIANS to UNDERSTAND That THE ACCEPTANCE OF AN ARTICLE DOES NOT NECESSARILY MEAN $\triangle$ RECOMMENDATION, BUT THAT SO FAR AS KNOWN IT COMPLIEY WITH THE RLLES ADOPTED BY THE COUNCIL.

\section{W. A. PUCKNER, Secretakr.}

(For a list of all accepted articles, see advertising page 22.) CORYFIN.

ETHYLGLYCOLIC ACID ESTER OF MENTHOL. Coryfin, $\mathrm{CH}_{2}\left(\mathrm{O} \cdot \mathrm{C}_{2} \mathrm{H}_{5}\right) \cdot \mathrm{COO}\left(\mathrm{C}_{10} \mathrm{H}_{19}\right)=\mathrm{C}_{14} \mathrm{H}_{26} \mathrm{O}_{3}$, is the ethylglycolic acid ester of menthol.

1. Miinch. med. Wochschr., 1906, liii, p. 819
It is prepared by the action of ethyloxyacetyl chloride on menthol. Coryfin is a limpid, colorless oil, having a very faint menthol odor. It boils under $20 \mathrm{~mm}$. pressure at about $155^{\circ} \mathrm{C}$. cultly soluble in water.

When heated with caustjc alkalles it is split up into mentho and ethylglycolic acid. When incinerated on platinum foil it leaves no resldue. Aqueous solutions must not have an acid reaction and must be free from chlorine and sulphuric acid.

Actions and Uses.-Soon after its application to the skin or mucous membranes a cooling effect is produced, said to be due to the splitting off of menthol, to which the pharmacologic actions of the remedy are to be ascribed.

Coryfin is said to be useful as a substitute for menthol in nervous headaches, coryza and conditions of hoarseness and pharyngeal irritation.

Dosage.-In headache it may be lightly rubbed in or painted on the forehead, avoiding contact with the eyes; in coryza it may be applied to the mucous membrane with a brush or as a spray. In throat affections a few drops ( 3 or 4 ) may be placed on a lump of sugar and allowed to dissolve in the mouth, or mixed with tepid water and used as a gargle.

Manufactured by Farbenfabriken vorm. Friedr. Bayer \& Co., Flberfeld, Germany (Farbenfabriken of Elberfeld Co. New York). U. S. patent No. 836914 . U. S. trademark No. 43416 .

NOVASPIRIN.

METHYLENE-CITRYLSALICYLIC ACID.<smiles>C=CCCOC(=O)CCC(CC(=O)O)C(=O)OCC(=O)O</smiles>

is methylene-citrylsalicylic acid.

Novaspirin is prepared by the action of methylene citric acid dichloride on salicylic acid.

Novasplrin is a white, odorless, crystalline powder, having a faint acidulous taste. It is easily soluble in alcohol, difficultly soluble in chloroform, ether, and scarcely soluble in water. It contains 62 per cent. of salicylic acid.

On heating with caustic alkalies salicylic acid is generated. On prolonged standing with water and more easily with alkalies it is split up into its components. When heated in a test tube it melts with the generation of formaldehyde. On adding dilute acid to the warm alkaline solution, white crystals of salicylic

Actions and Uses.-Novaspirin is not decomposed in the stomach and is said to be non-irritating to that organ, but it is broken up in the intestine into salicylic acid and methylenecitric acid.

It is said to be useful in influenza, coryza, tonsillitis, rheumatic conditions, gout and neuralgic conditions.

Dosage.-1 $\mathrm{Gm}$. (15 grains) several times daily.

Manufactured by Farbenfabriken vorm. Friedr. Bayer \& Co., Elberfeld, Germany (Farbenfabriken of Elberfeld Co., New York) U. S. patent No. 858142 , U. S. trademark No. 62613 .

( $T o$ be continued.)

How to Expose Every Inch of Surface in a Room to the Sunlight.-A French architect, A. Rey, has been making a special study of building houses to conform to the strictest hygienic requirements. THE JourNal has summarized some of his communications in which he proposed a number of innovations which would revolutionize the present system of building apartment houses, flats, etc., to secure the maximum of light and air without waste of space. In an article in Hygiène Génćrale et Appliquée for October he gives illustrations and diagrams claiming that it is possible to have the rays of light entering the window refracted or reflected in such ways as to cover every inch of flon and wall surface. This is accomplished by making the windows larger, and by having the ceiling merge into the rear wall in a long curve, starting about the center of the ceiling and gradually curving into the roar wall, the curve finishing at a point about three-fourths of the distance between ceiling and floor. This tangential curve reflects and refracts the rays of light, according to principles frequently encountered in nature for the reflection of light by means of curved surfaces, as he explains. 